\title{
Evaluation and reporting of CSR in SME sector
}

Justyna Szczanowicz, MA University of Zielona Góra Prof. Eng. Sebastian Saniuk University of Zielona Góra

\section{Introduction}

Conditions for running a business are changing rapidly and social reality and general living conditions are also constantly transforming. Furthermore, the network of relations between these two spheres is becoming more intense and complex. Overlapping boundaries between work and domestic life are one such example. The development of science, technology and access toa widevariety of solutions resultsinsituations where choices between environmentally friendly and unsustainable solutions are being made within the framework of existing law. It is worth, therefore, considering issues related to Corporate Social Responsibility (CSR). It is a concept whereby companies take responsibility for the impact of their decisions and activities on society and the environment (Makuch 2011, p. 20). The decision-making processes go beyond the legal requirements by investing in maximizing stakeholder value and minimizing adverse impact (European Commission 2011, p. 7).

In 2001, the European Commission (EC) drew attention to the fact that the corporate social responsibility concept is mainly driven by large companies, pointing to the need for its implementation in the sector of small and 
medium-sized enterprises (SMEs) (Commission of The European Communities 2001, p. 3). The SME sector generates almost half of Polish GDP, thus is an important backbone of the domestic economy; it is therefore important to work on solutions that would support the development of CSR in this sector.

This article aims to assess the condition of CSR in the SME sector in Poland and to propose a conceptual model of CSR evaluation and reporting in small and medium-sized enterprises.

\section{Corporate Social Responsibility - definition}

Since the Lisbon Strategy in 2000, the European Commission has been supporting and promoting CSR. In a statement published in 2011, the Commission defines CSR as "the responsibility of enterprises for their impact on society" (European Commission 2011, p. 6). Along with this simplified definition it is stressed that a prerequisite for meeting that responsibility is respect for the applicable legislation and collective agreements between the social partners. Special attention is being paid to close cooperation with stakeholders with the aim of: (European Commission 2011, p. 7):

- maximizing the creation of shared value for their owners/shareholders and for other stakeholders and society at large,

- identifying, preventing and mitigating their possible adverse impacts.

In the seventies, A.B. Carroll (1993) had already drawn attention to the different types of social responsibility, defined and arranged them in the form of a pyramid, suggesting what kind of activities are fundamental for the concept and which ones should be prioritized. Figure 1 shows the hierarchy, which is based on economic liability (profitability), the second type of responsibility is law, and the third one is ethics (expected by the public). At the top of the hierarchy A.B. Carroll (1993, p. 31) placed philanthropy, understood as using corporate wealth for public benefit and for solving societal problems.

To sum up, two different issues should be noticed. The first one concerns the complexity of CSR in the vertical context (referring to Caroll's pyramid). Different types of corporate social responsibility should be recognized as a hierarchy of priorities, where the foundations are the obligations towards society based on law and universally recognized ethical standards. Philanthropy and related kinds of activities undertaken in order to improve life quality of stakeholders could be defined as higher needs - by analogy to Maslow's pyramid (1990, p. 72). At this point two approaches to CSR are addressed: active and passive. "The passive approach is recommended to avoid harming the stakeholders

97 
and the environment. Companies therefore should always restrain from socially harmful activities. The active approach requires actions for overcoming negative social impact and to prevent it. (Rybak 2004, p. 28). The second issue is to consider CSR in the vertical context, striving for excellence and efficiency at every level of the pyramid, with companies working for the benefit of their stakeholders and their competitive advantage.

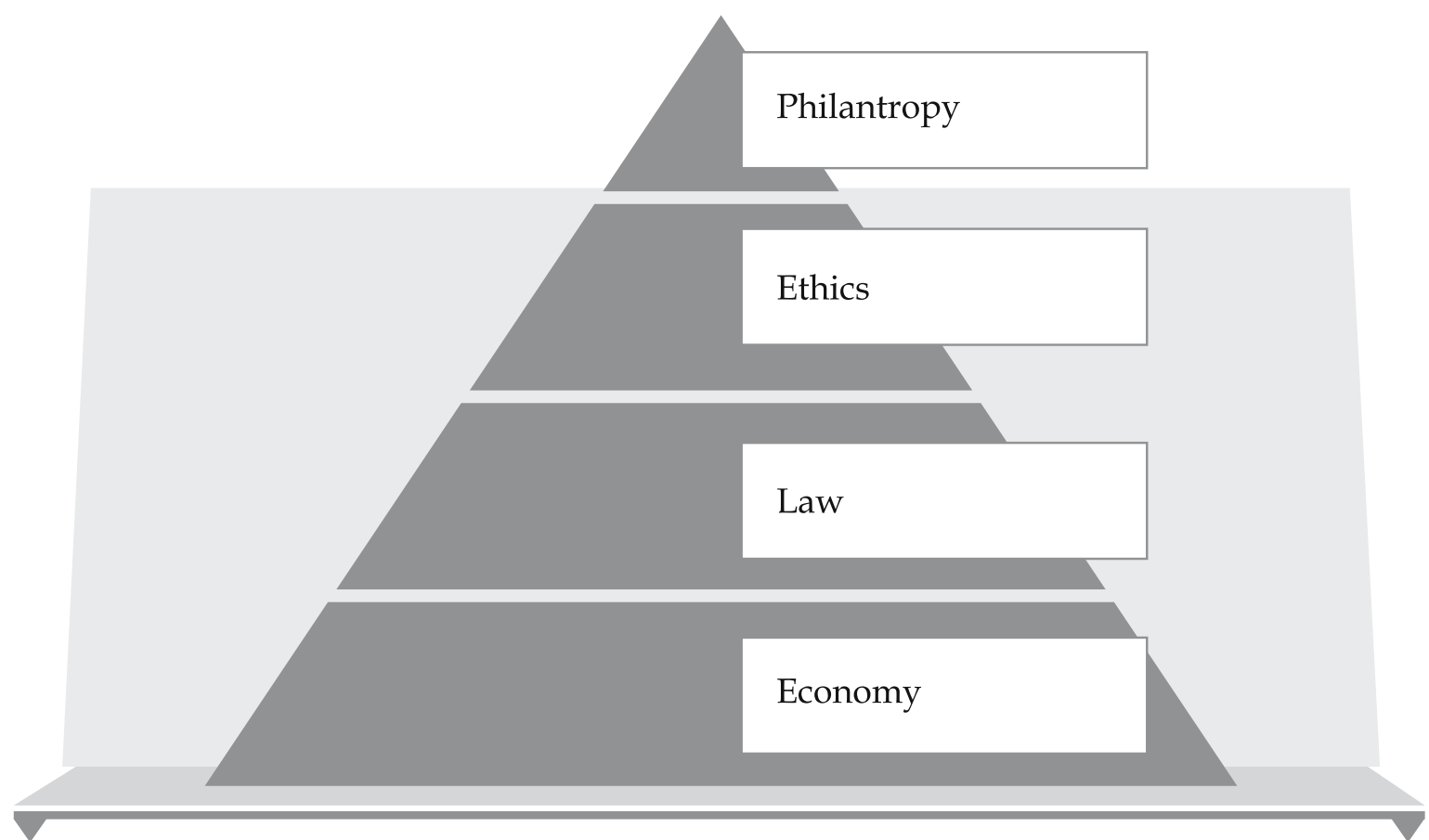

Figure 1. Types of social responsibilities according to A. B. Caroll

Source: Caroll 1993, p. 31

Stakeholder management is one of basic components of Corporate Social Responsibility. According to AA1000 relevant stakeholders are those individuals, groups of individuals or organisations that affect and/or could be affected by an organisation's activities, products or services and associated performance with regard to the issues to be addressed by the engagement (Accountability 2011, p.20). Groups, significantly affected by economic activities are: owners (shareholders), management, employees, suppliers, customers, local communities and future generations (Stocki 2012, p.31). The literature on the subject stresses the importance of stakeholder involvement in the implementation of CSR. In 
this context involvement implies a two-way dialogue with stakeholders at all stages of implementation, starting with planning, by carefully studying stakeholders' needs, through the implementation and evaluation of effects, as well as transparent communication (Szczanowicz, Saniuk 2014, pp. 74-75).

\section{The Polish SME sector and CSR}

In 2001, the European Commission (EC) drew attention to the fact that the corporate social responsibility concept is mainly driven by large companies pointing to the need for its implementation in the sector of small and mediumsized enterprises (SMEs) (Commission Of The European Communities 2001, p. 3). Since then, the necessity of CSR implementation in SMEs had been broadly discussed, while at the same time studies show poor levels of social responsibility in the sector.

A study conducted in 2013 by the Polish Agency for Enterprise Development on managers of micro, small and medium enterprises (MSMEs) shows that as many as $64 \%$ of respondents are not aware of the CSR concept. Among those who are aware of the concept the question was examined of what actions, in their opinion, indicate CSR implementation in a company. The most popular answer was "professional, fair and lawful business activity" (Polish Agency for Enterprise Development, Polska Agencja Rozwoju Przedsiębiorczości 2013, p. 14). However, it appears that entrepreneurs do not recognize that the obligations of this type are being imposed on operators' by legal and ethical obligations. Naturally, these issues are fundamental for CSR, nevertheless Corporate Social Responsibility should go beyond these basic social expectations (Polish Agency for Enterprise Development, Polska Agencja Rozwoju Przedsiębiorczości 2013 , p.15). It can be concluded that the problem lies in understanding CSR in relation to the legal requirements - mandatory, and those arising from the needs of stakeholders. It seems that companies do not recognize a variety of types and levels of social responsibility and therefore activities, risks and benefits associated with the concept.

An interesting result is the high "percentage of enterprises declaring actions corresponding to the CSR concept (special attention to its impact on workers - $80,42 \%$, environment - $82,83 \%$, and on the local community 75.15\%)"(Polish Agency for Enterprise Development, Polska Agencja Rozwoju Przedsiębiorczości 2013, p. 27). It can therefore be concluded that SMEs have a high potential for implementation of the CSR concept. However, the study shows that the company's approach to actions related to the concept is characterized 
by randomness and lack of a system. Answers provided by the respondents mostly indicate an intuitive understanding of the CSR issues. There is definitely a lack of strategy and orientation on effects in the context of use of the concept to increase competitiveness. All the more, it was noted that a low percentage of companies pay attention to the dialogue in order to become familiar with the needs of the community $(2.43 \%)$. A lack of dialogue surely means that the companies are not aware of the needs and expectations of the groups under the company's impact. Equally important is the lack of communication in the opposite direction. Moreover, the study does not address reporting of the results of the actions undertaken.Transparency is an important principle of the concept of Corporate Social Responsibility. Despite clear potential for Polish SMEs to be socially responsible, there is a need for demarcation between higher values of CSR and what is a company's absolute legal and ethical obligation as a member of society.

The level of CSR implementation in polish SMEs should be weighed against needs in this area. Those could be expressed by the expectations of consumers, business partner's requirements and criteria for allocation of EU subsidies. Consumers expect social responsibility from companies; this was evidenced by a study "Consumer Barometer" carried out in 2013 by Maison Research House and SGS Poland (2013). Results of the study show that Poles positively assess actions linked to CSR. As many as $81 \%$ of respondents think that companies should take actions towards environment or community. Moreover, among those who positively assess companies conducting CSR activities (62\%, while for $35 \%$ it does not matter) as many as $78 \%$ declare increased trust for the company, $76 \%$ are willing to purchase its products or use its services, $75 \%$ share positive experiences with the company with others, $71 \%$ are more loyal and $55 \%$ are willing to work in such a company. An interesting result is the consumer attitude towards reporting. While 66 percent of respondents believe that companies should openly talk about their activities for the common good, only $44 \%$ trust what companies say about it. In addition, $52 \%$ of respondents would like to have more information and $14 \%$ - a lot more. Thus there is a need for research and actions in order to improve the credibility of reporting environmental and social issues (Maison Research House and SGS Poland 2013).

In the near future, the driving force for responsible entrepreneurship in the SME sector may also be requirements imposed by large business partners. In April 2014, the European Parliament passed a legislative proposal aimed at mandatory reporting of non-financial information among EU enterprises. 
As a result of this "large undertakings, which are public-interest entities exceeding on their balance sheet dates the criterion of the average number of 500 employees during the financial year" (European Parliament 2014, p. 2), are obliged to include within management reports environmental and social aspects of their activities. The resolution draws particular attention to supply chain management and contractors in order to identify current or potential adverse effects, to prevent or mitigate those within the company's sphere of influence (European Parliament 2014). It should be emphasized that the paragraph on supply chain and subcontractors may lead to a situation where not only large companies will be obliged to monitor and report ESG aspects but also smaller entities including SMEs might face such a task.

Meeting the social needs and sustainable development concept may also prove to be profitable when applying for European Union grants. According to provisions of the Multiannual Financial Framework for the period 2014-2020, the total allocation for Poland for the period amounts to approx. 82.5 billion (Ministry of Infrastructure and Development, 2014, p. 159). Such a large sum, designated for the implementation of the EU guidelines by 2020, could certainly motivate companies to undertake actions that fit the vision. The European Union (EU) strategy for the development of Member States enshrined in "Europe 2020 " is based on competitiveness and sustainable development, along with social inclusion. The first priority designated to the Member State economies addresses development based on knowledge and innovation. Another raises the issue of sustainable development, thus supporting the economy to be more resource efficient, greener and more competitive. The third and last priority refers to inclusive growth and thus fostering economy with high-employment, economy delivering social and territorial cohesion (European Commission 2010 , p. 5). Clearly, when awarding grants from the 2014-2020 budget, activities that bring new quality and unconventional solutions are preferred. Moreover, companies focused on social issues and on the protection of the environment will also fit in the EU strategy, hence it will be significantly easier for them to obtain funding.

Consumer expectations, trends focused on sustainable development and concerns for social welfare are leading to CSR being imposed on the SME sector. However, the poor condition of CSR implementation in small and mediumsized enterprises (PARP research) may suggest a lack of solutions that would support the process. Hence the need for research towards solutions which are practical and results-oriented, but also flexible enough to be accessible for SMEs. 


\section{The concept of the CSR evaluation model in small and medium-sized enterprises}

The proposed approach to corporate social responsibility in small and medium-sized enterprises is based on an evaluation model. Analysis of the standardized model aims to highlight the potential of the company - what it has already succeeded in and indicate directions for further improvement. Integral parts of the model are a tool for management and reporting on ESG risks on the basis of KPI methodology and a catalog of ESG factors. In this approach, the model is a starting point for any activities related to CSR. Implementation, ongoing management, reporting and evaluation of CSR in the context of the efficiency should refer to a standardized reference model, which in this case also serves as a tool for evaluation.

The method is designed for the needs of small and medium-sized companies in particular due to its accessibility, simple structure and flexibility. The model is not only accessible because of its simple structure as evaluation model, but also introduces some order in the understanding of the concept in practice and shows directions towards different types of efficiency. It is of great importance to respect the levels of Corporate Social Responsibility. The starting point is an establishment and acceptance of the three levels hierarchy (figure 2). This assumes that building a business's competitive advantage on socially responsible activities is the highest level of CSR maturity and its reliability will result from robust ethical foundations, based on respect towards the rights and needs of groups in the zone of influence of the organization.

At the first level (the lowest) the entrepreneur should ask himself whether his company is trying to meet obligatory requirements, imposed by the country it operates in and specific for relevant sector. One of the key benefits of managing legal aspects is cost reduction associated with mitigating financial sanctions for failure to comply with legislation.

At the second level of evaluation, the entrepreneur examines whether the activity of the company causes any harm for its stakeholders. At this stage, dialogue with stakeholders is of great importance. Stakeholders should be provided with information on available communication channels designated for passing information on how a company's activities affects their lives and what are their needs.

In the case of any harm or negative impact, the company should undertake corrective and preventive actions (Campbell 2007, p. 951). Effectiveness at this 
stage will mean reducing the real and potential negative impacts on society and the environment. This stage corresponds to the level of ethical responsibility in the A.B. Caroll's model and passive approach.

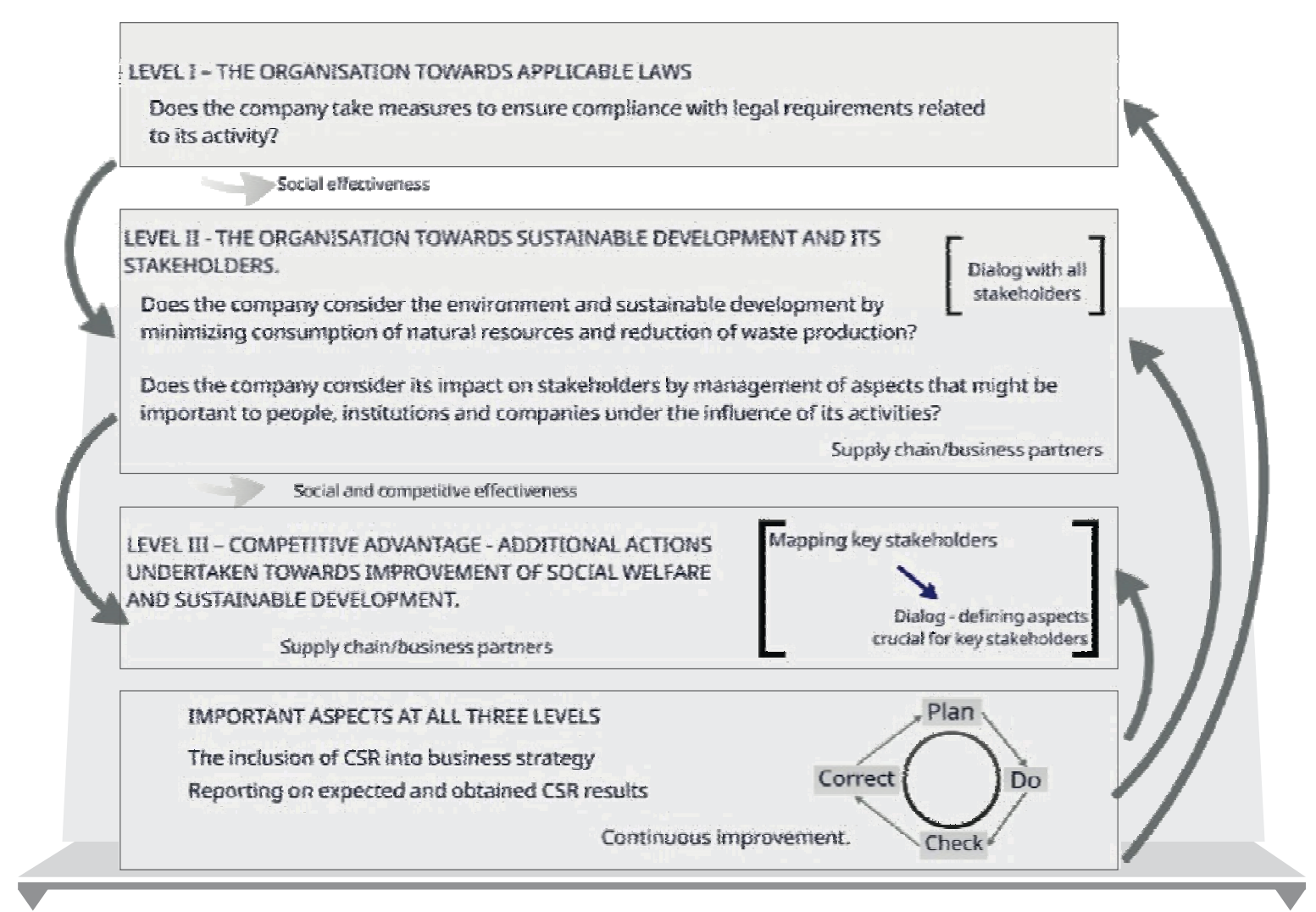

Figure 2. CSR evaluation model for SME's

Source: own study

When evaluating the latter two levels, it is advised to pay attention to the criteria for the selection of business partners in the supply chain. SMEs cannot afford a professional analysis of corporate social responsibility in their supply chain, including the monitoring of incidents of breaching internationally recognized ethical standards or activities to the detriment of stakeholders. However, at a minimum it is worth including in the evaluation at least the positive actions of the company's business partners, as those are usually reported on their websites, for example, certifications, or systems indicating care for environment and local society. 
According to the European Commission, the complexity of corporate social responsibility in the SME sector should depend on the size and nature of its activities, hence the model assumes flexibility and is referential. Incorporation of CSR into business strategy, identification, analysis and management of ESG risks (environmental, social and organizational) and reporting are important issues, however it is crucial to be realistic when it comes to capabilities of the smallest companies in the sector.

Identification and ESG risks management in the SME sector should be facilitated by access to a catalogue of aspects that should be taken under consideration during evaluation. For the needs of work on this method, an ESG risks catalogue for manufacturing companies was created, as this profile is particularly vulnerable to environmental, social and organizational risks (table 1).

Table 1. ESG risk areas in a manufacturing enterprise

\begin{tabular}{|c|c|c|}
\hline Environment & Social & Governance \\
\hline $\begin{array}{l}\text { GHG emissions } \\
\text { Energy efficiency } \\
\text { Leaks of hazardous substances } \\
\text { Radioactive waste } \\
\text { Production waste recycle and } \\
\text { re-use } \\
\text { Product life cycle } \\
\text { Eco-design } \\
\text { Sustainable packaging } \\
\text { Packaging } \\
\text { Lifecycle } \\
\text { Eco-design } \\
\text { Reclamation of land } \\
\text { deforestation } \\
\text { Fleet Management }\end{array}$ & $\begin{array}{l}\text { Occupational rights } \\
\text { Human rights } \\
\text { Product quality } \\
\text { Defectiveness of goods } \\
\text { The complaint procedures } \\
\text { Accidents at work } \\
\text { Child labour } \\
\text { Discrimination (gender, age, } \\
\text { orientation, ethnic minorities) } \\
\text { Staff turnover } \\
\text { Information provided on labels } \\
\text { Relations with local commu- } \\
\text { nities }\end{array}$ & $\begin{array}{l}\text { Corruption } \\
\text { Litigation risks } \\
\text { Timeliness of deliveries and } \\
\text { payments } \\
\text { High ESG risks in the supply } \\
\text { chain or in the investment } \\
\text { portfolio } \\
\text { Risks related to Corporate } \\
\text { Governance codes for listed } \\
\text { companies }\end{array}$ \\
\hline
\end{tabular}

Source: own study based on Ocieczek, Gajdzik 2010, pp. 98,99; Paliwoda-Matiolańska 2009, pp. 153; The European Federation of Financial Analysis Societies, Society Of Investment Professionals In Germany 2010; Stowarzyszenie Emitentów Giełdowych 2013

The catalog is a kind of checklist, whose role is to bring the enterpreneur's attention to risks specific to the sector in which he operates. An enterpreneur identifies risks crucial for his operations. In order to manage the risks effectively, success indicators should be determined along with actions undertaken to reduce or eliminate the risks. 
An important aspect of the concept is reporting on how a company manages ESG risks. Hence, a basis for responsible dialog with stakeholders should be a tool based on a measurable data, presented in a tabular form in order to ensure comparability, transparency and indicate progress. KPI (key performance indicators) methodology could be effective in pursuing this goal. Based on this methodology, the tool presented in Table 2 assumes the information is presented in a measurable way, based on specific indicators that give a clear picture of the implementation of previously intended objectives and plans for the future. This approach is enhanced to meet the needs of stakeholders and thus shows the effectiveness of actions taken within the framework of social entrepreneurship (Szczanowicz, Saniuk 2014, p. 75).

Table 2. A tool for reporting on ESG records over years

\begin{tabular}{c|c|c|c|c|c|c|c}
\hline $\mathbf{0}$ & $\mathbf{1 .}$ & $\mathbf{2 .}$ & $\mathbf{3 .}$ & $\mathbf{4 . 1}$ & $\mathbf{4 . 2}$ & $\mathbf{5 . 1}$ & $\mathbf{5 . 2}$ \\
\hline Risk & Action & Indicator & $\begin{array}{c}\text { Starting } \\
\text { point } \\
-2013\end{array}$ & $\begin{array}{c}\text { Planned } \\
\text { KPI for } \\
2014\end{array}$ & $\begin{array}{c}\text { KPI } \\
\text { achieved } \\
\text { in 2014 }\end{array}$ & $\begin{array}{c}\text { Planned } \\
\text { KPI for } \\
2015\end{array}$ & $\begin{array}{c}\text { KPI } \\
\text { achieved } \\
\text { in } 2015\end{array}$ \\
\hline $\begin{array}{c}\text { Work } \\
\text { acci- } \\
\text { dents }\end{array}$ & $\begin{array}{c}\text { Introducing a } \\
\text { communication } \\
\text { channel for re- } \\
\text { porting a poten- } \\
\text { tially dangerous } \\
\text { situation }\end{array}$ & $\begin{array}{c}\text { Number of } \\
\text { accidents }\end{array}$ & 4 & 0 & 2 & 0 & \\
\hline $\begin{array}{c}\text { Safety } \\
\text { on } \\
\text { roads }\end{array}$ & $\begin{array}{c}\text { Relieving traffic } \\
\text { through inter- } \\
\text { modal transport }\end{array}$ & $\begin{array}{c}\text { The propor- } \\
\text { tion of goods } \\
\text { transported } \\
\text { by rail }\end{array}$ & $5 \%$ & $8 \%$ & $8 \%$ & $15 \%$ & \\
\hline
\end{tabular}

Source: own study

The proposed method can be used regardless of the level of knowledge or implementation of CSR in the organization. Companies that have not implemented corporate social responsibility and have not taken actions associated with the concept, will focus on the first two levels. The third one might be the next step for them towards competitive advantage. Companies that manage CSR / undertake actions linked to the concept, however do so in an unorganized manner, casual, characterized by low efficiency, can use the evaluation as a catalyst for changes towards effectiveness. Hence, the advancement and improvement of social 
responsibility in a company can go in two directions: vertical and horizontal. A company can work on progress at all the levels at the same time, however it is of great importance to recognize the priorities (ethical and legal obligations) that build a robust foundation for social responsibility that could bring benefits to society and business. The model is also applicable to larger companies and business environment institutions as a standardized tool for the evaluation of CSR in organizations of various kinds.

\section{Conclusions}

The need for corporate social responsibility (CSR) is imposed by globalization, which amplifies the business not only in a positive sense, but also results in predatory competition. Aiming at highest profitability, entities often use practices contrary to the law or those not legally forbidden but nevertheless having a detrimental or adverse impact on stakeholders or sustainable development. According to M. Eiseneger (2009, p.20) the consequences of the economic crisis manifested themselves not only in poor financial results, but also caused some social effects. It has resulted in a gigantic crisis of trust and reputation for the entire economic system. Hence, the need to rebuild social trust, not only through relevant legislation but also through an economy based on social responsibility, understood as transparency of decisions and actions, as well as stakeholder involvement.

The role of Corporate Social Responsibility is to drive all the players of economy towards ventures aimed at minimizing the negative impacts of their activities. By following this concept enterprises of all sizes not only contribute to social welfare, but also - through a strategic approach - build their value and competitive advantage. This is particularly important in the case of small and medium-sized enterprises, as it is increasingly difficult for them to compete with large international corporations. In this case, their small sizes and simple organizational structures give them a potential advantage in the local market. SMEs often have direct contact with the local community, so they are able to respond quickly by undertaking socially meaningful actions, thus building good relations and a competitive advantage.

\section{Summary}

\section{Evaluation and reporting of CSR in the SME sector}

This article is an attempt to propose a CSR evaluation and CSR reporting model in small and medium-sized enterprises. Special 
attention was given to trends which reveal the need for CSR development in practice with particular emphasis on efficiency understood in two aspects: first one related to social welfare and sustainable development and the second one as a competitive advantage.

The new approach is based on a flexible tool for the evaluation and reporting of CSR, which also acts as a reference model for improvement of responsible entrepreneurship. An evaluation model, ESG risks catalog for manufacturing companies and a tool for monitoring and reporting of ESG risks were developed. Further work will include refinement of the method of evaluation model, including reporting tools and ESG risks catalogs for other sectors.

Keywords: Corporate Social Responsibility, CSR, Small and Medium Enterprises, evaluation, reporting.

\section{Streszczenie}

\section{Ewaluacja i raportowanie CSR w sektorze MŚP}

W artykule zaproponowano koncepcję modelu ewaluacji i raportowania CSR w małych i średnich przedsiębiorstwach. Zwrócono szczególną uwagę na uwarunkowania, zktórych wynika potrzeba rozwoju koncepcji CSR w praktyce ze szczególnym uwzględnieniem orientacji na efektywność rozumianą $\mathrm{w}$ dwóch aspektach: dobrobytu społecznego i zrównoważonego rozwoju oraz wykorzystania koncepcji do budowania przewagi konkurencyjnej.

Zaproponowano podejście oparte na elastycznym narzędziu do ewaluacji i raportowania CSR, które pełni również funkcję wystandaryzowanego modelu referencyjnego, dla określania kierunków doskonalenia odpowiedzialnej przedsiębiorczości. Opracowano model ewaluacyjny, katalog ryzyk ESG dla przedsiębiorstw produkcyjnych oraz narzędzie do nadzoru i raportowania ryzyk ESG. Dalsza praca nad metodą obejmie uszczegółowienie modelu ewaluacyjnego oraz opracowanie narzędzia do raportowania całej ewaluacji oraz wypracowaniu katalogów ryzyk ESG dla pozostałych sektorów. 
Słowa

kluczowe: Społeczna Odpowiedzialność Biznesu, CSR w sektorze MŚP, ewaluacja, raportowanie CSR.

\section{References}

1. AccountAbility (2011), AA1000 Stakeholder Engagement Standard 2011, Final Exposure Draft, http://www.accountability.org/images/content/3/6/362/AA1000SES\%202010\%20PRINT.PDF (27.01.2016 - access date).

2. Campbell J. (2007), Why would corporations behave in socially responsible ways? An institutional theory of Corporate Social Responsibility, "Academy of Management Review" Vol. 32, No. 3.

3. Caroll A. B. (1993), Business and Society: Ethics and Stakeholder Management, wyd. 2 College Division South-Western Publishing Co, Cincinnati.

4. Commission Of The European Communities (2001), Green Paper. Promoting a European framework for Corporate Social Responsibility, Brussels. http:/ / eur-lex.europa.eu/legal-content/EN/TXT/?uri=celex:52001DC0366 (27.01.2016 - access date).

5. Commission Of The European Communities (2003), Responsible entrepreneurship A collection of good practice cases among small and medium-sized enterprises across Europe, Brussels, http://info.worldbank.org/etools/docs/ library/114199/Responsible\%20Entrepreneurship\%20EU\%202003.pdf (27.01.2016 - access date).

6. Davis K., Blomstrom R. (1975), Business and society: Environment and responsibility, McGraw-Hill, New York.

7. Dom Badawczy Maison i SGS Polska (2013), BAROMETR CSR Wybrane wyniki pierwszej edycji badania opinii konsumentów w Polsce, http:// odpowiedzialnybiznes.pl/public/files/Broszura_Barometr\%20CSR_final-1378899134.pdf (27.01.2016 - access date).

8. Eisenegger M. (2009), Trust and reputation in the age of globalisation, in: J. Klewers, R. Wreschniok (eds.),. Reputation Capital. Building and Maintaining Trust in the 21st Century, Springer-Verlag, Berlin, Heidelberg.

9. European Commission (2010), Communication From The Commission Europe 2020 A Strategy For Smart, Sustainable And Inclusive Growth, Brussels, http:/ / ec.europa.eu/eu2020/pdf/COMPLET\%20EN\%20BARROSO $\% 20 \% 2020$ 007\% 20-\%20Europe \% 202020\% 20-\%20EN\% 20version.pdf(27.01.2016 access date).

10. European Commission(2011), Communication From The Commission To The European Parliament, The Council, The European Economic And Social Committee And The Committee Of The Regions A Renewed EU strategy 201114 for Corporate Social Responsibility, Brussels, http://eur-lex.europa.eu/ legal-content/PL/TXT/?uri=CELEX\%3A52011DC0681 (27.01.2016 - access date). 
11. Makuch Ł. (2011), Normy i standardy społecznej odpowiedzialności biznesu (CSR), Wyższa Szkoła Pedagogiczna TWP w Warszawie, Warszawa.

12. Maslow A.H. (1990),Motywacja i osobowość, PAX, Warszawa.

13. Ministerstwo Infrastruktury i Rozwoju (2014), Programowanie perspektywy finansowej 2014 -2020 - Umowa Partnerstwa, Warszawa, https:/ /www. mos.gov.pl/g2/big/2015_06/718069a9e4d43adc403971846295a5d1. $\operatorname{pdf}(27.01 .2016$ - access date)

14. Ocieczek W., Gajdzik B. (2010), Społeczna odpowiedzialność w przedsiębiorstwach produkcyjnych, Wydawnictwo Politechniki Śląskiej, Gliwice.

15. Paliwoda-Matiolańska A. (2009), Odpowiedzialność społeczna w procesie zarządzania przedsiębiorstwem, $\mathrm{CH}$ Beck, Warszawa.

16. Parlament Europejski (2014), Dyrektywa Parlamentu Europejskiego I Rady 2014/95/Ue Z Dnia 22 Października 2014 R. Zmieniająca Dyrektywe 2013/34/ UE W Odniesieniu Do Ujawniania Informacji Niefinansowych I Informacji Dotyczących Różnorodności Przez Niektóre Duże Jednostki Oraz Grupyhttp:// eur-lex.europa.eu/legal-content/PL/TXT/?uri=CELEX\%3A32014L0095, (27.01.2016 - access date).

17. Polska Agencja Rozwoju Przedsiębiorczości (2013), Badanie Kadry Zarzadzajacej W Ramach Projektu - Raport Z I Etapu Badania, http:/ /www. parp.gov.pl/ files/74/455/456/17648.pdf, (27.01.2016 - access date).

18. Polska Agencja Rozwoju Przedsiębiorczości (2014), Raport o stanie sektora matych i średnich przedsiębiorstw w Polsce w latach 2012-2013, Warszawa; http://www.parp.gov.pl/files/74/455/456/17648.pdf (27.01.2016 - access date).

19. Rybak M. (2004), Etyka manadżera. Społeczna Odpowiedzialność Przedsiębiorstwa, PWN, Warszawa.

20. Stocki R. (2012), Audyt etyczny organizacji, in: W. Gasparski (ed.), Biznes, etyka, odpowiedzialność,PWN, Warszawa.

21. Stoner J. A. F., Freeman R. E., Gilbert D. E., Jr (red.) (2011), Kierowanie, PWE, Warszawa.

22. Stowarzyszenie Emitentów Giełdowych (2013), Analiza ESG spótek w Polsce, Warszawa, http://seg.org.pl/pl/projekty/analiza-esg-spolek-w-polsce-ii-edycja (21.01.2016 - access date).

23. Internet address: http://.zak.grupaazoty.com/pl/rozwoj/produkcja/ bezpieczna (18.01.2016 - access date).

24. Internet address: http://barlinek.com.pl/pl/corporate/o-nas/179, grupa-barlinek.html (21.01.2016 - access date).

25. Internet address: http://bp.com/en/global/corporate/gulf-of-mexico-restoration.html (21.01.2016 - access date).

26. Internet address: http:/ / piskalski.centrumcsr.pl/?P=483 (21.01.2016 - access date).

27. Internet address: http://pkn.pl/sites/default/files/discovering_iso_ 26000.pdf (18.01.2016 - access date). 
28. Strona internetowa: http://www.barlinek.com.pl/pl/corporate/o-nas/179,grupa-barlinek.html (21.01.2016 - access date).

29. Szczanowicz J., Saniuk S. (2014), Implementationof CSR concept in manufacturing companies, "Management", Vol. 1.

30. The European Federation of Financial Analysis Societies, Society Of Investment Professionals In Germany (2010), Kpi's for esg a guaideline for the integration of esg into financial analysis and corporate valuation, version 3.0, DVFA, Frankfurt Am Main. http:/ / www.effas-esg.com/wp-content/ uploads/2011/07/KPIs_for_ESG_3_0_Final.pdf (27.01.2016 - access date). 